\title{
Faktor-Faktor Pengaruh Ukuran Urban Compactness di Kota Denpasar, Bali
}

\author{
I Putu Praditya Adi Pratama dan Putu Gde Ariastita \\ Jurusan Perencanaan Wilayah dan Kota, Fakultas Teknik Sipil dan Perencanaan, \\ Institut Teknologi Sepuluh Nopember (ITS) \\ Jl. Arief Rahman Hakim, Surabaya 60111 Indonesia \\ e-mail: ariastita@urplan.its.ac.id
}

\begin{abstract}
Abstrak-Urban sprawl mengakibatkan ketergantungan terhadap kendaraan pribadi, hilangnya luas dan fungsi ruang terbuka hijau, serta membentuk morfologi kota yang tidak teratur. Konsep kota kompak (compact city) muncul sebagai revitalisasi terhadap urban sprawl. Potensi penerapan konsep kota kompak pada suatu wilayah dapat dilihat melalui pengukuran urban compactness. Salah satu kota yang menghadapi kecenderungan perkembangan wilayah secara urban sprawl adalah Kota Denpasar. Tujuan dari penelitian ini adalah mengidentifikasi faktor-faktor yang mempengaruhi ukuran urban compactness Kota Denpasar. Faktor-faktor tersebut diidentifikasi melalui 2 tahapan analisis, yaitu mengidentifikasi karakteristik urban compactness Kota Denpasar, melalui metode deskriptif-kuantitatif, serta menentukan faktor-faktor yang mempengaruhi ukuran urban compactness di Kota Denpasar, melalui analisis regresi linier berganda metode stepwise. Penelitian ini menggunakan metode kuantitatif sebagai pendekatan penelitian.

Dari hasil penelitian ini, didapatkan 4 faktor yang mempengaruhi ukuran urban compactness Kota Denpasar secara kuantitatif, yaitu nilai kepadatan lahan terbangun, persentase konsentrasi luas permukiman, nilai keberagaman penggunaan lahan, serta persentase ketersediaan ruang terbuka hijau. Hasil penelitian ini dapat menjadi masukan bagi penelitian lanjutan terkait skenario dan intervensi konsep kota kompak dalam merumuskan bentuk struktur dan pola ruang Kota Denpasar yang lebih kompak dan berkelanjutan.
\end{abstract}

Kata Kunci-Kota kompak, urban compactness, urban sprawl.

\section{PENDAHULUAN}

$U$ $R B A N$ SPRAWL merupakan proses perembetan kenampakan fisik suatu kota ke arah luarnya [1]. Karakteristik perkembangan secara urban sprawl berupa single-use zoning, penggunaan lahan berkepadatan rendah, ketergantungan terhadap kendaraan pribadi, serta desain kota yang homogen [2]. Terjadinya urban sprawl berdampak pada hilangnya peran pusat kegiatan, ketergantungan terhadap kendaraan pribadi, serta hilangnya luasan dan fungsi ruang terbuka hijau perkotaan [3]. Melihat permasalahan tersebut, maka muncul beberapa konsep yang bertujuan merevitalisasi dampak negatif tersebut, salah satunya adalah konsep kota kompak (compact city). Konsep ini telah berhasil diterapkan sebagai pengendalian urban sprawl pada beberapa negara, di antaranya Belanda dan Inggris [4].

Penerapan konsep kota kompak berfokus pada intensifikasi perkotaan, membentuk batas pada pengembangan perkotaan, memberdayakan penggunaan lahan campuran, dan lebih berfokus pada kualitas transportasi publik dan urban design yang baik [3]. Pada beberapa aspek, prinsip penerapan konsep kota kompak terlihat bertolak belakang dengan karakteristik urban sprawl, karena konsep ini muncul sebagai perbaikan dari urban sprawl itu sendiri. Tujuan penerapan konsep kota kompak adalah tercapainya kesejahteraan sosial dan ekonomi masyarakat, serta keberlanjutan lingkungan perkotaan [5].

Kota Denpasar merupakan salah satu daerah yang sedang menghadapi permasalahan terkait urban sprawl. Peran fungsi Kota Denpasar sebagai pusat kegiatan pada Kawasan Sarbagita telah menimbulkan penyatuan fungsional serta timbulnya densifikasi permukiman Kota Denpasar pada wilayah pinggiran, atau membentuk urban sprawl [6]. Hal ini juga didukung oleh pembangunan Kota Denpasar yang cenderung berjalan secara vertikal, sehingga menimbulkan isu keterbatasan lahan, di mana penduduk Kota Denpasar telah tumbuh dari 335.196 Jiwa pada tahun 1992, menjadi 846.200 Jiwa pada tahun 2013 [7].

Melihat permasalahan tersebut, maka konsep kota kompak dapat difungsikan sebagai revitalisasi permasalahan urban sprawl yang dihadapi Kota Denpasar. Untuk melihat penerapan konsep tersebut, maka sebelumnya perlu diketahui ukuran urban compactness Kota Denpasar. Sebelumnya, faktor-faktor yang mempengaruhi ukuran urban compactness Kota Denpasar perlu diketahui sebagai dasar pengukurannya. Maka dari itu, rumusan permasalahan dalam penelitian ini adalah belum terumuskannya faktor-faktor yang mempengaruhi ukuran urban compactness Kota Denpasar. Berdasarkan permasalahan tersebut, maka tujuan dari penelitian ini adalah merumuskan faktor-faktor yang mempengaruhi ukuran urban compactness Kota Denpasar.

\section{METODE PENELITIAN}

\section{A. Metode Pengumpulan Data}

Pengumpulan data dalam penelitian ini dilakukan melalui metode primer dan sekunder. Secara umum, survey data yang dilakukan adalah survey sekunder, melalui studi literatur pada beberapa instansi pemerintahan, seperti Badan Pusat Statistik Provinsi Bali, Badan Pusat Statistik Kota Denpasar, Badan Perencanaan Pembangunan Daerah Kota Denpasar, serta Dinas Tata Ruang dan Perumahan Kota Denpasar. Kedalaman 


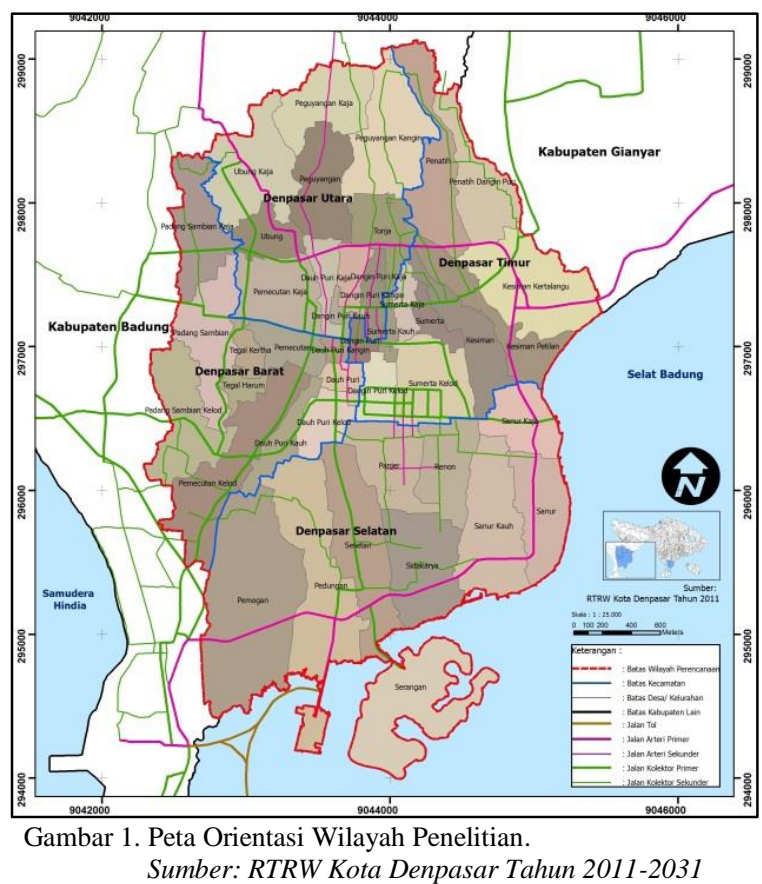

unit wilayah penelitian yang diambil mencakup desa dan kelurahan di seluruh Kota Denpasar.

Pengecualian terjadi dalam identifikasi variabel tingkat penggunaan kendaraan pribadi, yang diidentifikasi melalui survey primer dengan penyebaran kuisioner. Hal ini dikarenakan keterbatasan data literatur yang dapat digunakan dalam mengidentifikasi variabel ini. Pada perhitungan sampel penyebaran kuisioner melalui metode random sampling [8], dengan tingkat kesalahan 0,1 , didapatkan bahwa jumlah minimal kuisioner yang disebarkan adalah 129 pada seluruh desa dan kelurahan di Kota Denpasar.

\section{B. Metode Analisis}

Metode analisis dalam mencapai tujuan penelitian terdiri dari 2 tahapan analisis sebagai berikut.

\section{Mengidentifikasi karakteristik urban compactness Kota Denpasar}

Analisis ini dilakukan melalui metode deskriptif-kuantitatif terhadap 12 variabel yang menjelaskan karakteristik urban compactness Kota Denpasar. Tujuan dari tahapan analisis ini adalah mengidentifikasi karakteristik kuantitatif dari urban compactness di Kota Denpasar.

\section{Menentukan faktor-faktor yang mempengaruhi ukuran urban compactness Kota Denpasar}

Analisis ini dilakukan melalui analisis regresi linier berganda metode stepwise. Tujuan dari tahapan analisis ini adalah menentukan faktor-faktor yang terbukti signifikan mempengaruhi urban compactness Kota Denpasar, melalui uji statistik antara 11 variabel urban compactness sebagai variabel bebas dengan indeks urban compactness Kota Denpasar sebagai variabel terikat.

Metode analisis selengkapnya dapat dilihat pada Tabel 1.
Tabel 1.

Metode Analisis Penelitian

\begin{tabular}{|c|c|c|c|}
\hline Sasaran & $\begin{array}{l}\text { Masukan / } \\
\text { Input Data }\end{array}$ & Metode & Luaran/ Output \\
\hline \multirow{12}{*}{$\begin{array}{l}\text { 1. Mengidenti- } \\
\text { fikasi } \\
\text { karakteristik } \\
\text { urban } \\
\text { compactness } \\
\text { Kota } \\
\text { Denpasar }\end{array}$} & $\begin{array}{l}\text { Jumlah } \\
\text { penduduk (Jiwa) }\end{array}$ & \multirow{12}{*}{$\begin{array}{l}\text { Deskriptif- } \\
\text { kuantitatif }\end{array}$} & $\begin{array}{l}\text { Kepadatan } \\
\text { lahan terbangun }\end{array}$ \\
\hline & $\begin{array}{l}\text { Luas lahan } \\
\text { terbangun (ha) }\end{array}$ & & $\begin{array}{l}\text { Kepadatan } \\
\text { permukiman }\end{array}$ \\
\hline & $\begin{array}{l}\text { Luas lahan } \\
\text { permukiman } \\
\text { (ha) }\end{array}$ & & $\begin{array}{l}\text { Persentase } \\
\text { konsentrasi luas } \\
\text { permukiman }\end{array}$ \\
\hline & $\begin{array}{l}\text { Luas ruang } \\
\text { terbuka hijau } \\
\text { (ha) }\end{array}$ & & $\begin{array}{l}\text { Tingkat } \\
\text { keberagaman } \\
\text { penggunaan } \\
\text { lahan }\end{array}$ \\
\hline & $\begin{array}{l}\text { Luas wilayah } \\
\text { (ha) }\end{array}$ & & \multirow{4}{*}{ 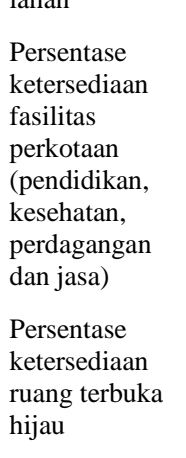 } \\
\hline & $\begin{array}{l}\text { Nilai proporsi } \\
\text { penggunaan } \\
\text { lahan campuran }\end{array}$ & & \\
\hline & $\begin{array}{l}\text { Jumlah jenis } \\
\text { penggunaan } \\
\text { lahan }\end{array}$ & & \\
\hline & $\begin{array}{l}\text { Jumlah unit } \\
\text { fasilitas } \\
\text { perkotaan }\end{array}$ & & \\
\hline & $\begin{array}{l}\text { Standar } \\
\text { ketersediaan } \\
\text { fasilitas } \\
\text { perkotaan (SNI } \\
\text { 03-1773-2004) }\end{array}$ & & $\begin{array}{l}\text { Persesntase } \\
\text { penggunaan } \\
\text { kendaraan } \\
\text { pribadi }\end{array}$ \\
\hline & $\begin{array}{l}\text { Jumlah } \\
\text { penggunaan } \\
\text { jenis kendaraan }\end{array}$ & & $\begin{array}{l}\text { Persentase } \\
\text { pertumbuhan } \\
\text { penduduk }\end{array}$ \\
\hline & $\begin{array}{l}\text { Jumlah } \\
\text { penduduk time } \\
\text { series selama } 5 \\
\text { tahun (Jiwa) }\end{array}$ & & $\begin{array}{l}\text { Persentase } \\
\text { pertumbuhan } \\
\text { permukiman } \\
\text { baru }\end{array}$ \\
\hline & $\begin{array}{l}\text { Jumlah luas } \\
\text { pekarangan time } \\
\text { series selama } 5 \\
\text { tahun (ha) }\end{array}$ & & $\begin{array}{l}\text { Indeks urban } \\
\text { compactness }\end{array}$ \\
\hline $\begin{array}{l}\text { 2. Menentukan } \\
\text { faktor-faktor } \\
\text { yang } \\
\text { mempenga- } \\
\text { ruhi ukuran } \\
\text { urban } \\
\text { compactness } \\
\text { Kota } \\
\text { Denpasar }\end{array}$ & $\begin{array}{l}\text { Variabel- } \\
\text { variabel yang } \\
\text { merepresentasik } \\
\text { an urban } \\
\text { compactness } \\
\text { Kota Denpasar }\end{array}$ & $\begin{array}{l}\text { Analisis } \\
\text { regresi } \\
\text { linier } \\
\text { berganda } \\
\text { metode } \\
\text { stepwise }\end{array}$ & $\begin{array}{l}\text { Faktor-faktor } \\
\text { yang } \\
\text { mempengaruhi } \\
\text { ukuran urban } \\
\text { compactness } \\
\text { Kota Denpasar }\end{array}$ \\
\hline
\end{tabular}

Sumber: Hasil Analisis, 2015

\section{HASIL DAN PEMBAHASAN}

\section{A. Karakteristik urban compactness Kota Denpasar}

Variabel-variabel urban compactness Kota Denpasar merepresentasikan 3 indikator utama konsep kota kompak, yaitu kepadatan, fungsi campuran, dan intensifikasi. Perhitungan setiap variabel dapat dilihat pada pembahasan berikut ini. 


\section{Kepadatan Lahan Terbangun}

Kepadatan lahan yang tinggi merupakan salah satu ciri utama penerapan konsep kota kompak [9]. Rumus perhitungan nilai kepadatan lahan terbangun Kota Denpasar adalah:

Kepadatan Lahan Terbangun $(\mathrm{Jiwa/ha})=$

$$
\frac{\text { Jumlah Penduduk (Jiwa) }}{\text { Luas Lahan Terbangun (ha) }}
$$

Hasil perhitungan memperlihatkan bahwa kepadatan lahan terbangun Kota Denpasar memiliki ketimpangan yang cukup tinggi, di mana Desa Tegal Kertha memiliki nilai kepadatan 987,52 Jiwa/ ha sebagai nilai tertinggi, sedangkan Desa Dangin Puri Kauh hanya memiliki nilai kepadatan 54,81 Jiwa/ ha sebagai yang terendah. Hasil ini memperlihatkan belum efektifnya penggunaan lahan di Kota Denpasar.

\section{Kepadatan Permukiman}

Konsep kota kompak mendorong terciptanya keadilan sosial melalui bentuk permukiman yang berkepadatan tinggi, yang mendukung terpenuhinya kebutuhan kehidupan sehari-hari masyarakat [4]. Tingkat kepadatan permukiman menjelaskan efisiensi pemanfaatan lahan permukiman suatu kota. Rumus perhitungan nilai kepadatan permukiman Kota Denpasar adalah:

\section{Kepadatan Lahan Permukiman $($ Jiwa/ ha $)=$}

$$
\frac{\text { Jumlah Penduduk (Jiwa) }}{\text { Luas Lahan Permukiman (ha) }}
$$

Hasil perhitungan memperlihatkan bahwa kepadatan lahan terbangun Kota Denpasar memiliki ketimpangan yang cukup tinggi, di mana Desa Tegal Kertha memiliki nilai kepadatan $1.416,71 \mathrm{Jiwa} /$ ha sebagai yang tertinggi, sedangkan Desa Dangin Puri Kauh hanya memiliki nilai kepadatan 61,42 Jiwa/ ha sebagai yang terendah. Hasil ini memperlihatkan belum efektifnya pemanfaatan permukiman di Kota Denpasar.

\section{Persentase Konsentrasi Luas Permukiman}

Penyediaan permukiman di Kota Denpasar tidak dapat dimaksimalkan dalam bentuk vertikal, karena terbentur peraturan tinggi bangunan maksimal, yaitu 15 meter (Perda Provinsi Bali No, 16 Tahun 2009 tentang RTRW Provinsi Bali, Pasal 95 Ayat (2), Butir b). Oleh karena itu, konsentrasi permukiman yang tinggi di Kota Denpasar dapat diperlihatkan dalam proporsi penggunaan lahan sebagai permukiman yang tinggi. Rumus perhitungan persentase konsentrasi luas permukiman Kota Denpasar adalah:

\section{Persentase Konsentrasi Permukiman (\%) =

$$
\frac{\text { Luas Permukiman (ha) }}{\text { Luas Wilayah (ha) }} \times 100 \%
$$

Hasil perhitungan memperlihatkan bahwa penyediaan permukiman pada Kota Denpasar masih terpusat pada bagian inti kota, di mana Desa Sumertha Kauh memiliki persentase konsentrasi luas permukiman tertinggi dengan nilai 91,94\%, serta Kelurahan Serangan sebagai yang terendah dengan nilai $3,87 \%$.

\section{Keberagaman Penggunaan Lahan}

Penggunaan lahan campuran membantu kota yang kompak menjadi lebih efisien dan efektif, dengan memperkecil jarak perjalanan [10]. Bentuk kuantitatif dari keberagaman penggunaan lahan diukur melalui perhitungan indeks entropi (EI) [11]. Rumus perhitungan indeks entropi Kota Denpasar adalah:

$$
E I=\sum_{t=1}^{n} K i \cdot \log \left(\frac{1}{K i}\right) / \log (N)
$$

Keterangan :

$\mathrm{EI}=$ Indeks entropi keberagaman penggunaan lahan pada masing-masing desa/ kelurahan di Kota Denpasar;

$\mathrm{Ki}=$ Nilai relatif (proporsi) sub-area atau atribut; serta

$\mathrm{N}=$ Jumlah sub-area atau atribut.

Sumber: Permatasari, 2013

Hasil pengukuran indeks entropi Kota Denpasar menunjukkan range yang cukup rendah $(0-0,167)$, di mana nilai tertinggi yang dapat dicapai adalah 1 . Dari hasil ini, dapat disimpulkan bahwa keberagaman penggunaan lahan di Kota Denpasar masih sangat rendah.

\section{Persentase Ketersediaan Fasilitas Pendidikan}

Salah satu karakteristik kunci dari konsep kota kompak adalah aksesibilitas dan keterjangkauan yang tinggi terhadap fasilitas pelayanan lokal [5], di antaranya fasilitas pendidikan. Ketersediaan fasilitas pendidikan Kota Denpasar diukur dengan memperbandingkan ketersediaan unit SD, SMP, dan SMA dengan standar yang berlaku dalam SNI 03-1773-2004 tentang Tata Cara Perencanaan Lingkungan Perumahan di Perkotaan. Rumus perhitungan persentase ketersediaan fasilitas pendidikan Kota Denpasar adalah:

$$
\begin{aligned}
& \text { Persentase Ketersediaan Fasilitas Pendidikan (\%) }= \\
& {\left[\text { Jumlah Unit } /\left(\frac{\text { Jumlah Penduduk }}{\text { Standar Ketersediaan }}\right)\right] \times 100 \%}
\end{aligned}
$$

Hasil perhitungan memperlihatkan bahwa ketersediaan fasilitas pendidikan Kota Denpasar masih terpusat pada bagian inti kota, dengan Desa Dangin Puri Kangin terlayani fasilitas pendidikan dengan persentase tertinggi $242,94 \%$, sedangkan Kelurahan Dauh Puri hanya terlayani 7,53 \% dari standar pelayanan minimal fasilitas pendidikan sebagai yang terendah.

\section{Persentase Ketersediaan Fasilitas Kesehatan}

Selain fasilitas pendidikan, fasilitas kesehatan juga merupakan fasilitas dasar yang dapat dijadikan ukuran compactness suatu wilayah. Ketersediaan fasilitas kesehatan Kota Denpasar diukur dengan memperbandingkan ketersediaan unit posyandu, puskesmas, praktek dokter, serta rumah sakit bersalin dengan standar yang berlaku dalam SNI 03-1773-2004 tentang Tata Cara Perencanaan Lingkungan Perumahan di Perkotaan. Rumus perhitungan persentase ketersediaan fasilitas kesehatan Kota Denpasar adalah: 
Persentase Ketersediaan Fasilitas Kesehatan $(\%)=$

$$
\left[\text { Jumlah Unit } /\left(\frac{\text { Jumlah Penduduk }}{\text { Standar Ketersediaan }}\right)\right] \times 100 \%
$$

Hasil perhitungan memperlihatkan bahwa ketersediaan fasilitas kesehatan di Kota Denpasar sudah cukup baik, di mana sebagian besar desa dan kelurahan telah memiliki persentase ketersediaan $\geq 100 \%$. Desa Sanur Kaja memiliki persentase ketersediaan tertinggi dengan nilai $358,28 \%$, sedangkan Desa Pemogan menjadi yang terendah dengan nilai $33,67 \%$.

\section{Persentase Ketersediaan Fasilitas Perdagangan \& Jasa}

Selain fasilitas pendidikan dan kesehatan, fasilitas perdagangan dan jasa juga merupakan fasilitas dasar yang dapat dijadikan ukuran compactness suatu wilayah. Ketersediaan fasilitas perdagangan dan jasa Kota Denpasar diukur dengan memperbandingkan ketersediaan unit pasar umum dan pertokoan dengan standar yang berlaku dalam SNI 03-1773-2004 tentang Tata Cara Perencanaan Lingkungan Perumahan di Perkotaan. Rumus perhitungan persentase ketersediaan fasilitas perdagangan dan jasa Kota Denpasar adalah:

Persentase Ketersediaan Fasilitas Perjas (\%) =

$$
\left[\text { Jumlah Unit } /\left(\frac{\text { Jumlah Penduduk }}{\text { Standar Ketersediaan }}\right)\right] \times 100 \%
$$

Hasil perhitungan memperlihatkan bahwa ketersediaan fasilitas perdagangan dan jasa di Kota Denpasar sudah cukup baik, di mana sebagian besar desa dan kelurahan telah memiliki persentase ketersediaan $\geq 100 \%$. Desa Dauh Puri Kangin memiliki persentase ketersediaan tertinggi dengan nilai 1005,15 \%, sedangkan Kelurahan Dangin Puri Kaja menjadi yang terendah dengan nilai $20,32 \%$.

\section{Persentase Ketersediaan Ruang Terbuka Hijau (RTH)}

Walaupun kota kompak direpresentasikan dengan kepadatan yang tinggi dan kadang mendekati perkembangan kota yang berjejal, tetapi kota kompak tetap mengutamakan ketersediaan RTH [3]. Rumus perhitungan persentase ketersediaan RTH Kota Denpasar adalah:

Persentase Ketersediaan RTH $(\%)=$

$$
\frac{\text { Luas Ruang Terbuka Hijau (ha) }}{\text { Luas Wilayah (ha) }} \times 100 \%
$$

Hasil perhitungan memperlihatkan bahwa ketersediaan RTH pada Kota Denpasar cukup baik, di mana 25 dari 43 desa dan kelurahan di Kota Denpasar memiliki persentase ketersediaan di atas $30 \%$, atau di atas standar penyediaan RTH perkotaan yang ditetapkan dalam UU No. 26 Tahun 2007 tentang penataan ruang. Kelurahan Serangan memiliki persentase ketersediaan tertinggi dengan nilai 91,331\%, sedangkan Desa Dangin Puri Kauh menjadi yang terendah dengan nilai $0,00 \%$.

\section{Persentase Tingkat Penggunaan Kendaraan Pribadi}

Konsep kota kompak menyebabkan berkurangnya ketergantungan terhadap kendaraan pribadi [4], sehingga tingkat kendaraan pribadi dapat dijadikan ukuran compactness suatu wilayah. Sebuah wilayah yang memiliki tingkat penggunaan kendaraan pribadi lebih rendah telah mampu meminimalisir jarak perjalanan dan membentuk sistem transportasi yang bertumpu pada kendaraan non-pribadi. Rumus perhitungan persentase tingkat penggunaan kendaraan pribadi Kota Denpasar, adalah:

$$
\begin{aligned}
& \text { Persentase Tingkat Penggunaan Kendaraan Pribadi (\%) } \\
& \qquad=\frac{\text { Jumlah sampel kegiatan menggunakan }}{\text { Jumlah total sampel kegiatan }} \times 100 \%
\end{aligned}
$$

Hasil perhitungan memperlihatkan persentase penggunaan kendaraan pribadi di Kota Denpasar masih menunjukkan nilai yang tinggi, di mana masyoritas desa dan kelurahan memiliki persentase di atas $60 \%$. Hasil ini memperlihatkan pola transportasi masyarakat Kota Denpasar masih belum mengarah kepada terwujudnya kota kompak.

\section{Persentase Pertumbuhan Penduduk}

Salah satu indikator compactness suatu wilayah adalah kepadatan dan pertumbuhan penduduk ke bagian dalam wilayah [12]. Pertumbuhan penduduk yang tinggi akan berpengaruh pada proses intensifikasi sebuah wilayah menuju kota yang kompak [4]. Rumus perhitungan persentase pertumbuhan penduduk Kota Denpasar, adalah:

\section{Persentase Pertumbuhan Penduduk (\%) =}

$$
\frac{\text { Jumlah Penduduk Tahun 2013-2008 (Jiwa) }}{\text { Jumlah Penduduk Tahun } 2008} \times 100 \%
$$

Hasil perhitungan memperlihatkan bahwa pertumbuhan penduduk Kota Denpasar selama 5 tahun $(2008$ - 2013) terjadi lebih tinggi pada wilayah pinggiran Kota Denpasar. Desa Padang Sambian Klod memperlihatkan persentase pertumbuhan tertinggi dengan nilai $120,63 \%$, sedangkan Kelurahan Dangin Puri memperlihatkan penurunan jumlah penduduk sebesar $-21,51 \%$ sebagai yang terendah.

\section{Persentase Pertumbuhan Permukiman Baru}

Intensifikasi permukiman ke dalam wilayah merupakan salah satu elemen utama terbentuknya kota kompak [12]. Rumus perhitungan persentase pertumbuhan permukiman baru Kota Denpasar, adalah:

\section{Persentase Pertumbuhan Permukiman Baru (\%) =

$$
\frac{\text { Kepadatan Permukiman }}{\text { Tahun 2013-2008 (ha) }}
$$

Hasil perhitungan memperlihatkan bahwa pertumbuhan permukiman Kota Denpasar selama 5 tahun (2008 - 2013) terjadi lebih tinggi pada wilayah pinggiran Kota Denpasar. Desa Ubung Kaja memperlihatkan persentase pertumbuhan tertinggi dengan nilai 120,63 \%, sedangkan Kelurahan Dauh Puri memperlihatkan penurunan kepadatan permukiman sebesar $-26,95 \%$ sebagai yang terendah. Hal ini memperlihatkan pesatnya pertumbuhan pada wilayah pinggiran Kota Denpasar, terutama selama periode tahun 2008 - 2013, yang mendukung fakta bahwa terjadi perkembangan wilayah secara sprawl pada Kota Denpasar. 


\section{Indeks Urban Compactness Kota Denpasar}

Indeks urban compactness Kota Denpasar diukur melalui metode kuantifikasi yang dilakukan oleh D. Stahakis dan G. Tsilikmigkas [13]. Indeks tersebut didapatkan melalui kombinasi indeks densifikasi dan indeks mixed use. Kedua indeks tersebut kemudian distandardisasi dan dikombinasikan menjadi indeks urban compactness. Rumus perhitungan indeks urban compactness Kota Denpasar adalah:

$$
\begin{aligned}
& \text { Indeks Densifikasi }= \\
& \begin{array}{r}
\text { Kepadatan Penduduk + Kepadatan Permukiman } \\
+ \text { Kepadatan Lahan Terbangun } \\
(\text { Jiwa } / \text { ha })
\end{array}
\end{aligned}
$$

Indeks Mixed Use =

$\frac{\text { Luas Penggunaan Lahan Permukiman (ha) }}{\text { Luas Penggunaan }}$
Lahan Terbangun - Luas Penggunaan
Lahan Permukiman (ha)

Kedua indeks tersebut kemudian distandardisasi dan dikombinasikan menjadi indeks urban compactness menggunakan persamaan berikut ini.

\section{Indeks Urban Compactness $=$}

$$
\frac{\text { Indeks Densifikasi }+ \text { Indeks Mixed Use }}{2}
$$

Dari hasil analisis, didapatkan bahwa Desa Tegal Kertha memiliki nilai urban compactness tertinggi dengan nilai 2,559, sedangkan Kelurahan Sanur memiliki nilai terendah dengan nilai -0,828. Semakin tinggi nilai urban compactness, maka dapat disimpulkan bahwa struktur compactness wilayah tersebut lebih terbentuk. Compactness Kota Denpasar masih rendah, terlihat dari banyaknya wilayah yang memiliki nilai negatif.

\section{B. Faktor-faktor yang mempengaruhi ukuran urban compactness Kota Denpasar}

Dalam analisis regresi linier berganda, variabel bebas yang digunakan adalah nilai kepadatan lahan terbangun (X1), nilai kepadatan lahan permukiman (X2), persentase luas konsentrasi permukiman (X3), nilai keberagaman penggunaan lahan (X4), ketersediaan fasilitas perkotaan [fasilitas pendidikan (X5), fasilitas kesehatan (X6), serta fasilitas perdagangan dan jasa (X7)], persentase ketersediaan RTH (X8), tingkat penggunaan kendaraan pribadi (X9), persentase pertumbuhan penduduk (X10), serta persentase pertumbuhan permukiman baru (X11), yang telah dianalisis pada sasaran pertama. Variabel terikat yang digunakan adalah nilai dari indeks urban compactness Kota Denpasar (Y). Melalui uji asumsi klasik, keseluruhan variabel telah memenuhi kriteria identik, independent, dan berdistribusi normal. Variabel diuji menggunakan nilai alfa pengujian sebesar $0,05-0,1$.

Berdasarkan hasil analisis regresi linier berganda metode stepwise, berikut ini merupakan model regresi yang menginterpretasikan faktor-faktor yang mempengaruhi ukuran urban compactness Kota Denpasar secara signifikan.

$$
\mathrm{Y}=-2321+0,003(\mathrm{X} 1)+0,027(\mathrm{X3})+3,281(\mathrm{X} 4)+\mathbf{0 , 0 0 8}(\mathrm{X8})
$$

Keterangan :

Y : Nilai urban compactness;

X1 : Nilai kepadatan lahan terbangun (Jiwa/ ha);

X3 : Persentase luas konsentrasi permukiman (\%);

X4 : Nilai keberagaman penggunaan lahan; serta

X8 : Persentase ketersediaan ruang terbuka hijau (\%).

Sumber: Hasil Analisis, 2015

Berdasarkan model regresi yang dihasilkan, terdapat 4 faktor yang signifikan mempengaruhi ukuran urban compactness Kota Denpasar dalam bentuk Y, yaitu nilai kepadatan lahan terbangun, luas konsentrasi permukiman, keberagaman penggunaan lahan, serta ketersediaan ruang terbuka hijau. Variabel lain tidak diakomodasi pada model regresi, terkait dengan nilai signifikansi yang tidak sesuai dengan nilai probabilitas F 0,05-0,1. Hal ini memperlihatkan bahwa variabel-variabel tersebut belum secara signifikan mempengaruhi tinggi rendahnya ukuran urban compactness Kota Denpasar.

Faktor kepadatan lahan terbangun memperlihatkan peran aspek densifikasi dalam membentuk compactness di Kota Denpasar. Tingginya kepadatan lahan terbangun membantu terwujudnya penggunaan lahan yang lebih efektif dengan mereduksi jangkauan terhadap pusat-pusat pelayanan, serta mewujudkan konservasi pada ruang terbuka hijau. Bagian inti Kota Denpasar memiliki kepadatan lahan terbangun lebih tinggi dibandingkan wilayah pinggiran, terlihat dari tingginya nilai pada wilayah-wilayah seperti Desa Tegal Harum $(349,73$ Jiwa/ ha) dan Kelurahan Sumerta (250,58 Jiwa/ ha). Desa Tegal Kertha yang memiliki nilai indeks urban compactness tertinggi (2,559), memiliki nilai kepadatan lahan terbangun tertinggi di Kota Denpasar, dengan 987,52 Jiwa/ ha. Hal ini memperlihatkan bahwa pemanfaatan lahan pada bagian pusat Kota Denpasar cukup efektif, yang membantu terbentuknya struktur yang lebih kompak pada wilayah tersebut.

Pentingnya penyediaan permukiman dalam membentuk struktur compactness Kota Denpasar terlihat pada faktor konsentrasi luas permukiman. Wilayah yang memiliki persentase konsentrasi luas permukiman tinggi, seperti Desa Sumerta Kauh (91,94 \%) dan Desa Dangin Puri Kauh (89,23 $\%)$ memiliki nilai urban compactness positif (1,201 dan 0,507). Dari hasil analisis, terlihat bahwa tingginya persentase luas konsentrasi permukiman terpusat pada bagian inti Kota Denpasar, yang juga mendukung tingginya nilai faktor kepadatan lahan terbangun pada wilayah ini dalam membentuk penggunaan lahan yang lebih efektif.

Persentase ketersediaan ruang terbuka hijau yang tinggi terpusat pada wilayah pinggiran Kota Denpasar, seperti Kelurahan Serangan (91,33 \%) dan Desa Kesiman Kertalangu $(69,82 \%)$. Hal ini memperlihatkan bahwa kota yang kompak juga harus mempertahankan ketersediaan ruang terbuka hijau, baik dalam fungsi ekologis maupun rekreasi. Densifikasi Kota Denpasar yang masih terpusat pada bagian inti memberikan ruang bagi konservasi lahan pada wilayah pinggiran sebagai ruang terbuka hijau kota. 
Walaupun nilai keberagaman penggunaan lahan di Kota Denpasar masih rendah, terlihat dari range indeks entropi 0,000 - 0,167 , faktor ini masih menjadi aspek yang penting dalam menentukan tinggi rendahnya struktur compactness Kota Denpasar. Keberagaman penggunaan lahan pada wilayah pinggiran Kota Denpasar lebih tinggi, seperti Desa Pemecutan Klod $(0,167)$ dan Kelurahan Kesiman $(0,165)$, memperlihatkan mulai hilangnya fungsi pusat kota, khususnya pada aspek penggunaan lahan campuran. Dengan nilai yang masih rendah, faktor keberagaman penggunaan lahan perlu mendapatkan perhatian khusus dalam mewujudkan struktur dan pola ruang Kota Denpasar yang lebih kompak dan berkelanjutan.

\section{KESIMPULAN/ RINGKASAN}

Berdasarkan keseluruhan pembahasan dalam penelitian ini, maka dapat ditarik kesimpulan sebagai berikut:

1. Karakteristik urban compactness Kota Denpasar menunjukkan ketimpangan pada aspek kepadatan, terutama pada kepadatan lahan terbangun dan kepadatan permukiman. Hal ini memperlihatkan belum intensifnya pemanfaatan lahan pada Kota Denpasar. Permukiman lebih terkonsentrasi pada bagian inti kota, memperlihatkan belum efektifnya penyediaan permukiman pada wilayah pinggiran Kota Denpasar, namun hal ini juga memperlihatkan potensi pada aspek lain, di mana ketersediaan RTH masih cukup tinggi pada wilayah tersebut. Ketersediaan fasilitas kesehatan serta fasilitas perdagangan dan jasa memperlihatkan persentase yang cukup tinggi di Kota Denpasar, akan tetapi ketersediaan fasilitas pendidikan masih bergantung pada pusat kota. Tingkat penggunaan kendaraan pribadi Kota Denpasar masih cukup tinggi, memperlihatkan belum terwujudnya pola pergerakan yang berkelanjutan di Kota Denpasar. Sementara itu, selama periode tahun 2008 - 2013, pertumbuhan penduduk dan permukiman baru lebih tinggi pada wilayah pinggiran Kota Denpasar, mendukung fakta bahwa terjadi sprawling di Kota Denpasar.

2. Berdasarkan uji statistik melalui analisis regresi linier berganda, ukuran urban compactness Kota Denpasar dipengaruhi oleh beberapa faktor, yaitu nilai kepadatan lahan terbangun, persentase luas konsentrasi permukiman, nilai keberagaman penggunaan lahan, serta persentase ketersediaan ruang terbuka hijau. Semakin tinggi nilai keempat faktor tersebut, maka compactness pada suatu desa/ kelurahan di Kota Denpasar semakin terbentuk, terlihat dari semakin tingginya nilai urban compactness pada wilayah tersebut. Ketujuh variabel urban compactness, selain keempat variabel yang diakomodasi oleh hasil persamaan regresi, belum menunjukkan pengaruh yang signifikan terhadap tinggi rendahnya nilai ukuran urban compactness di Kota Denpasar pada alfa pengujian 0,05-0,1. Melihat hasil tersebut, dapat disimpulkan bahwa keempat variabel yang masuk ke dalam persamaan regresi merupakan faktor-faktor yang mempengaruhi ukuran urban compactness Kota Denpasar saat ini secara signifikan.

\section{UCAPAN TERIMA KASIH}

Penulis I.P.P.A.P mengucapkan terima kasih kepada Bapak Putu Gde Ariastita, ST., MT., yang telah membimbing Penulis hingga mampu menyelesaikan penelitian ini. Penulis juga mengucapkan terima kasih kepada pihak-pihak terkait yang telah membantu terselesaikannya penelitian ini.

\section{DAFTAR PUSTAKA}

[1] Giyarsih, Sri Rum. 2001. Gejala Urban Sprawl Sebagai Pemicu Proses Densifikasi Permukiman di Daerah Pinggiran Kota (Urban Fringe Area) : Kasus Pinggiran Kota Yogyakarta. Jurnal PWK Volume 12, Nomor 1, Maret 2001.

[2] Nallathiga, Ramakrisna. 2008. Contradictions of Sustainable Urban Development : The Choice of Choice of Compact City Development Approach. ITPI Journal, $5: 2$ (2008), 55 - 59.

[3] Daneshpour, Abdolhadi \& Shakibamanesh, Amir. 2011. Compact City, Does it Create an Obligatory Context for Urban Sustainability? International Journal of Architectural Enginering \& Urban Planning, Volume 21, Nomor 2, December 2011.

[4] Kustiwan, Iwan dkk. 2007. Pengukuran Compactness Sebagai Indikator Keberlanjutan Kota dan Kebutuhan Pengembangan Compact City pada Kawasan Tumbuh Pesat di Indonesia. SAPPK-ITB Research Series, Volume 3, 2007, Bandung.

[5] Matsumoto, Tadashi, Sanchez-Serra, Daniel, dan Ostry, Adam. 2012. Compact City Policies : A Comparative Assesment. OECD Green Growth Studies.

[6] Badan Perencanaan Pembangunan Daerah Kota Denpasar. 2011. Rencana Tata Ruang Wilayah (RTRW) Kota Denpasar Tahun 2011 2031. Bappeda Kota Denpasar, Denpasar.

[7] Badan Pusat Statistik Kota Denpasar Tahun. 2014. Kota Denpasar Dalam Angka 2014. BPS Kota Denpasar, Denpasar.

[8] Sevilla, Consuelo dkk. 1993. Pengantar Metode Penelitian. Universitas Indonesia Press, Jakarta.

[9] Roychansyah, M. Sani. 2006. Paradigma Kota Kompak. Artikel. sabiroy.archiplan.ugm.ac.id, diakses 17 Maret 2014.

[10] Neuman, Michael. 2005. The Compact City Fallacy. Journal of Planning Education and Research Association of Collegiate Schools of Planning, Florida.

[11] Permatasari, Dhea dkk. 2013 Pengaruh Urban Compaction Terhadap Pola Pergerakan Berkelanjutan di Kota Surabaya. Planning for Urban Region and Environment Journal, Volume 2, Nomor 1, Januari 2013.

[12] Burgess, Rod \& Jenks, Mike. 2000. Compact Cities : Sustainable Urban Forms for Developing Countries. Spon Press, New York.

[13] Stathakis. D dan Tsilimigkas. G. Applying Urban Compactness Metrics On Pan-European Datasets. International Archives of The Photogrammetry, Remote Sensing, and Spatial Information Sciences, Volume XL-4/W1, 29th Urban Data Management Symposium, 29-31 May, 2013, London. 